\title{
ANALISIS KETERAMPILAN PROSES SAINS MELALUI PRAKTIKUM IPA MATERI BAGIAN-BAGIAN BUNGA DAN BIJI PADA MAHASISWA PGSD STKIP MUHAMMADIYAH BANGKA BELITUNG
}

\author{
Yuanita, M.Pd \\ STKIP Muhammadiyah Bangka Belitung \\ Yuanitaa87@gmail.com
}

\begin{abstract}
This study aims to analyze the ability of science process skill of students of PGSD STKIP Muhammadiyah Bangka Belitung on the science laboratory of the flower and seed sections, and analyze the difficulty of science process skill on the science lab. The sample used is PGSD students consisting of 42 students. The sampling technique used is simple random technique. Data collection tool consists of observation sheet, LKS, and interview. From the result of data analysis, it is known that the science process skill of PGSD study program on science process skill is high where the result shows the skill of using the tools and the materials with the average score is 76,4 in medium category, observation skill and observation with the average value is 81,4 in high category, grouping/classification capability with an average grade of 82.1 in high category and communicating ability with an average grade of 82.8 in high categories. From the interview result, it is found that PGSD students' difficulties are due to their social science field background when they were still in senior school and they are not accustomed to apply the science process skill especially the use of science process skill, materials.
\end{abstract}

\section{Keywords: science process skills, science Practicum}

\begin{abstract}
Abstrak: Penelitian ini bertujuan untuk menganalisis kemampuan keterampilan proses sains mahasiswa PGSD STKIP Muhammadiyah Bangka Belitung pada praktikum IPA materi bagian bunga dan biji dan analisis kesulitan keterampilan proses sains pada praktikum IPA. Sampel yang digunakan yaitu mahasiswa prodi PGSD yang terdiri dari 42 mahasiswa. Pengambilan sampel menggunakan teknik simple random sampling. Alat pengumpul data terdiri dari lembar observasi, LKS dan wawancara. Dari hasil analisis data diketahui bahwa keterampilan proses sains mahasiswa prodi PGSD pada keterampilan proses sains tergolong tinggi dimana hasil menunjukkan keterampilan menggunakan alat dan bahan dengan nilai rata-rata 76,4 kategori sedang, keterampilan mengamati dan mengobservasi dengan nilai rata-rata 81,4 kategori tinggi, kemampuan mengelompokkan/klasifikasi dengan nilai rata-rata 82,1 kategori kategori tinggi dan kemampuan mengkomunikasikan dengan nilai rata-rata 82,8 kategori tinggi. Dari hasil wawancara kesulitan mahasiswa PGSD pada Keterampilan Proses Sains saat praktikum IPA yaitu latar belakang bidang ilmu Sosial saat masih di Sekolah Menengah Atas sehingga tidak terbiasa dalam keterampilan Proses Sains terutama keterampilan Proses Sains penggunaan alat dan bahan.
\end{abstract}

Kata Kunci: Keterampilan Proses Sains, Praktikum Ipa.

\section{PENDAHULUAN}

Undang-undang nomor 20 tahun 2003 tentang Sistem Pendidikan Nasional menyebutkan dalam pasal 1 ayat 1, "Pendidikan merupakan usaha sadar dan terencana untuk mewujudkan suasana belajar dan proses pembelajaran agar peserta didik secara aktif mengembangkan potensi dirinya untuk memiliki kekuatan spiritual, keagamaan, pengendalian diri, kepribadian, kecerdasan, akhlak mulia, serta keterampilan yang diperlukan dirinya, masyarakat, bangsa dan Negara". Dari undang-undang tersebut bahwanya pendidikan harus membangun kualitas 
manusia yang berkualitas untuk kemajuan bangsa dan Negara.

LPTK merupakan salah satu sarana untuk menghasilkan manusia yang berkualitas terutama menghasilkan calon pendidik/guru salah satunya guru Sains. Melihat semakin maju peradaban semakin maju pula sains dan teknologi, perkembangan sains dan teknologi ini mengharuskan para guru untuk mengingkatkan kemampuan dan mengembangkan keahliannya. Paradigma baru dalam pembelajaran sains adalah pembelajaran dimana siswa tidak hanya dituntut untuk lebih banyak mempelajari konsep-konsep dan prinsipprinsip sains secara verbalistis, hafalan, pengenalan rumus-rumus, dan pengenalan istilah-istilah melalui serangkaian latihan secara verbal, namun hendaknya dalam pembelajaran sains, guru lebih banyak memberikan pengalaman kepada siswa untuk lebih mengerti dan membimbing siswa agar dapat menggunakan pengetahuannya tersebut dalam kehidupannya seharihari. Oleh sebab itu, dalam pembelajaran sains diperlukan kemampuan berfikir. Dengan demikian, sebagai hasil belajar sains diharapkan siswa memiliki kemampuan berfikir dan bertindak berdasarkan pengetahuan sains yang dimilikinya melalui kerangka berfikir sains terutama keterampilan proses sains.

Banyak sekali yang kurang memahami pentingnya keterampilan proses sains. Keterampilan proses sains ini sangat penting untuk mendidik anak menjadi lebih tanggap dan bisa berpikir kritis. Tugas terpenting guru adalah membangun keterampilan proses sains pada peserta didik salahsatunya melalui praktikum IPA.

Usman Samatowa (2006:137) mengemukakan bahwa keterampilan proses sains merupakan keterampilan intelektual yang dimiliki dan digunakan oleh para ilmuwan dalam meneliti fenomena alam.

Rustaman

(2005:95)

mendefinisikan keterampilan proses sains merupakan keterampilan yang diperlukan untuk memperoleh, mengembangkan dan menerapkan konsep-konsep, prinsip-prinsip, hukumhukum, dan teori sains, baik berupa keterampilan mental, keterampilan fisik (manual) maupun keterampilan sosial.

$$
\text { Dimyati dan Mudjiono }
$$

(2002:140) menjelaskan bahwa berbagai keterampilan dalam keterampilan proses terdiri dari keterampilan-keterampilan dasar dan keterampilan terintegrasi. Keterampilan dasar terdiri dari enam keterampilan, yaitu: mengobservasi, mengklasifikasi, memprediksi, mengukur, menyimpulkan, dan mengkomunikasikan. Keterampilan terintergrasi terdiri dari: mengidentifikasi variabel, membuat tabulasi data, menyajikan data dalam bentuk grafik, menggambarkan hubungan antar variabel, mengumpulkan dan mengolah data, menganalisis penelitian, menyusun hipotesis, mendefinisikan variabel secara operasional, merancang penelitian atau eksperimen.

Donna

(1994:241)

mengemukakan bahwa: Keterampilan proses Sains adalah teknik yang digunakan oleh ilmuwan dalam memperoleh informasi. Pada dasarnya, ini adalah keterampilan dan teknik yang ilmuwan di laboratorium untuk menemukan informasi baru tentang dunia. Keterampilan proses sains adalah teknik bahwa anak-anak yang menggunakan dalam mendapatkan informasi secara pengalaman pertama dari aktivitas atau kegiatan belajar siswa. Salah satu bentuk pembelajaran yang dapat memberikan pengalaman belajar adalah kegiatan praktikum. Kajian yang dilakukan pada penelitian ini berkaitan 
dengan matakuliah pratikum IPA materi bagian-bagian bunga dan biji Mahasiswa dengan panduan LKS mereka akan mengidentifikasi bunga dan biji. Oleh karena itu perlu dianalisis lebih jauh tentang bagaimana keterampilan proses sains yang ada pada pembelajaran praktikum IPA serta anaisis kesulitan keterampilan proses sains pada praktikum IPA. Penelitian ini bertujuan untuk mengetahui kemampuan keterampilan proses sains mahasiswa PGSD STKIP Muhammadiyah Bangka Belitung pada praktikum IPA materi bagian bunga dan biji, dan untuk menganalisis kesulitan keterampilan proses sains pada praktikum IPA

\section{KAJIAN PUSTAKA}

\section{a. Studi tentang praktikum IPA SD}

Praktikum merupakan bentuk latihan yang bertujuan untuk mengembangkan keterampilan dasar, seperti menggunakan alat, mengukur, dan mengamati. Berikut ini beberapa penelitian terkait dengan petunjuk praktikum IPA yang pernah dilaksanakan. Penelitian oleh I Gede Margunayasa dan puti Nanci (2014:356) mengatakan bahwa petunjuk praktikum IPA dapat berpengaruh terhadap pemahaman konsep IPA. Temuan peneliti terkait dengan penerapan petunjuk IPA pertama, dalam proses pemebelajaran bermakna harus memperhatikan pengetahuan awal mahasiswa dimana menjadi salah satu alternative dalam mengakomodasi pengetahuan awal mahasiswa dalam kegiatan praktikum. Kedua, dalam pembelajaran praktikum IPA lebih dianjurkan untuk menggunakan petunjuk praktikum IPA, hal ini dikarenakan dalam proses pembelajaran, mahasiswa dihadapkan kepaka pola pikir yang masih bersifat miskonsepsi kemudian sajian konsep ilmiah diperoleh mahasiswa setelah melakukan kegiatan praktikum yang tersaji dalam petunjuk praktikum IPA.

\section{b. Studi tentang Keterampilan Proses Sains SD}

Keterampilan proses Sains adalah merupakan kemampuan dasar dalam bereksperimen, metode ilmiah dan berinkuiri dalam sebuah pembelajaran. Keterampilan berarti kemampuan menggunakan pikiran, nalar, dan perbuatan secara efisien dan efektif untuk mencapai suatu hasil tertentu, termasuk kreativitas. Proses didefinisikan sebagai perangkat keterampilan kompleks yang digunakan ilmuwan dalam melakukan penelitian ilmiah. Proses merupakan konsep besar yang dapat diuraikan menjadi komponen-komponen yang harus dikuasai seseorang bila akan melakukan penelitian dan Sains (science) diambil dari kata latin scientia yang arti harfiahnya adalah pengetahuan. Juhji (2016:67) mengatakan bahwa untuk meningkatkan keterampilan proses sains siswa hendaknya dibiasakan untuk lebih banyak belajar sendiri agar bisa menemukan konsep-konsep, prinsip ilmiah, serta mengembangkan kreativitas dalam pemecahan masalahmasalah sains yang dalam pelaksanaannya dalam dbimbing guru secara intensif.

Rustaman (2007:5) memaparkan KPS secara rinci sebagai berikut.

1) Melakukan pengamatan (observasi)

Menggunakan indera penglihat, pembau, pendengar, pengecap, dan peraba pada waktu mengamati ciriciri semut, capung, kupu-kupu, dan hewan lain yang termasuk serangga merupakan kegiatan yang sangat dituntut dalam belajar IPA. Menggunakan fakta yang relevan dan memadai dari hasil pengamatan juga 
termasuk keterampilan proses mengamati.

2) Menafsirkan pengamatan (interpretasi)

Mencatat setiap hasil pengamatan tentang fermentasi secara terpisah antara hasil utama dan hasil sampingan termasuk menafsirkan atau interpretasi. Menghubunghubungkan hasil pengamatan tentang bentuk alat gerak dengan habitatnya menunjukkan bahwa siswa melakukan interpretasi. Begitu pula jika siswa menemukan pola atau keteraturan dari satu seri pengamatan tentang jenis-jenis makanan berbagai burung, misalnya semuanya bergizi tinggi, dan menyimpulkan bahwa makanan bergizi diperlukan oleh burung.

3) Mengelompokkan (klasifikasi)

Penggolongan makhluk hidup dilakukan setelah siswa mengenali ciri-cirinya. Dengan demikian dalam proses pengelompokkan tercakup beberapa kegiatan seperti mencari perbedaan, mengontraskan ciri-ciri, mencari kesamaan, membandingkan, dan mencari dasar penggolongan.

4) Meramalkan (prediksi)

Keterampilan meramalkan atau prediksi mencakup keterampilan mengajukan perkiraan tentang sesuatu yang belum terjadi berdasarkan suatu kecenderungan atau pola yang sudah ada. Memperkirakan bahwa besok matahari akan terbit pada jam tertentu di sebelah timur merupakan contoh prediksi.

5) Berkomunikasi

Membaca grafik, tabel atau diagram dari hasil percobaan tentang faktorfaktor yang mempengaruhi pertumbuhan atau pernapasan termasuk berkomunikasi dalam pembelajaran IPA. Menggambarkan data empiris dengan grafik, tabel, atau diagram juga termasuk berkomunikasi. Selain itu termasuk ke dalam berkomunikasi juga adalah menjelaskan hasil percobaan, misalnya mempertelakan atau memberikan tahap-tahap perkembangan daun, termasuk menyusun dan menyampaikan laporan secara sistematis dan jelas.

6) Berhipotesis

Hipotesis menyatakan hubungan antara dua variabel, atau mengajukan perkiraan penyebab sesuatu terjadi. Dengan berhipotesis diungkapkan cara melakukan pemecahan masalah, karena dalam rumusan hipotesis biasanya terkandung cara untuk mengujinya. Umpamanya, apabila ingin diketahui faktor-faktor yang mempengaruhi kecepatan tumbuh, dapat dibuat hipotesis:

"Jika diberikan pupuk NPK, akar tumbuhan A akan lebih cepat tumbuh".

Dalam hipotesis tersebut terdapat dua variabel (faktor pupuk dan cepat tumbuh), ada perkiraan penyebabnya (meningkatkan), serta mengandung cara

untuk mengujinya (diberi pupuk NPK).

7) Merencanakan percobaan atau penyelidikan

Beberapa kegiatan menggunakan pikiran termasuk ke dalam keterampilan proses merencanakan penyelidikan. Apabila dalam lembar kegaiatan siswa tidak dituliskan alat dan bahan secara khusus, tetapi tersirat dalam masalah yang dikemukakan, berarti siswa diminta merencanakan dengan cara menentukan alat dan bahan untuk penyelidikan tersebut. Menentukan variabel atau perubah yang terlibat dalam suatu percobaan tentang pengaruh pupuk terhadap laju pertumbuhan tanaman juga termasuk 
kegiatan merancang penyelidikan. Selanjutnya menentukan variabel kontrol

dan variabel bebas, menentukan apa yang diamati, diukur atau ditulis, serta

menentukan cara dan langkah kerja juga termasuk merencanakan penyelidikan. Sebagaimana dalam penyusunan rencana kegiatan penelitian perlu ditentukan cara mengolah data untuk dapat disimpulkan, maka dalam merencanakan penyelidikan pun terlibat kegiatan menentukan cara mengolah data sebagai bahan untuk menarik kesimpulan.

8) Menerapkan konsep atau prinsip

Setelah memahami konsep pembakaran zat makanan menghasilkan kalori, barulah seorang siswa dapat menghitung jumlah kalori yang dihasilkan sejumlah gram bahan makanan yang mengandung zat makanan. Apabila seorang siswa mampu menjelaskan peristiwa baru (misal banjir) dengan menggunakan konsep yang telah dimiliki (erosi dan pengangkutan air), berarti ia menerapkan prinsip yang telah dipelajarinya. Begitu pula apabila siswa menerapkan konsep yang telah dipelajari dalam situasi baru.

9) Mengajukan pertanyaan

Pertanyaan yang diajukan dapat meminta penjelasan, tentang apa, mengapa, bagaimana, atau menanyakan latar belakang hipotesis. Pertanyaan yang meminta penjelasan tentang pembahasan ekosistem menunjukkan bahwa siswa ingin mengetahui dengan jelas tentang hal itu. Pertanyaan tentang mengapa dan bagaimana keseimbangan ekosistem dapat dijaga menunjukkan si penanya berpikir. Pertanyaan tentang latar belakang hipotesis menunjukkan si penanya sudah memiliki gagasan atau perkiraan untuk menguji atau memeriksanya. Dengan demikian jelaslah bahwa bertanya tidak sekedar bertanya tetapi melibatkan pikiran.

\section{c. Studi tentang keterampilan berpikir kritis SD}

Keterampilan berpikir kritis merupakan kemampuan untuk memahami suatu permasalahan dan mencari solusi pemecahan masalahnya, serta selalu berpikiran terbuka terhadap hal-hal baru untuk menemukan solusi terbaik dari permasalahan yang dihadapi. Masalah dalam pembelajaran. Ilmu Pengetahuan Alam yang dipelajari di Sekolah Dasar adalah salah satu permasalahan yang mampu merangsang kemampuan siswa dalam berpikir kritis karena dengan menyelesaikan permasalahan pada mata pelajaran Ilmu Pengetahuan Alam siswa mampu berpikir secara kritis, logis dan ilmiah sehingga kemampuan mereka dalam berpikir kritis juga dapat terus dikembangkan. Menurut Hassoubah (2007: 87), berpikir kritis adalah "berpikir secara beralasan dan reflektif dengan menekankan pembuatan keputusan tentang apa yang harus dipercayai atau dilakukan". Sutrisno (2007: 1.19) menjelaskan bahwa di dalam Ilmu Pengetahuan Alam terdapat tiga pertanyaan mendasar yaitu apa yang terjadi?, bagaimana itu terjadi?, dan mengapa itu terjadi?. Jawaban dari pertanyaan-pertanyaan tersebut selain dapat membangun ilmu pengetahuan alam yang sedang dipelajari juga dapat merangsang kemampuan berpikir kritis siswa dalam mempelajari suatu hal. Mukhlis (2015:20) mengatakan dalam hasil penelitiannya untuk meningkatkan kemampuan berpikir kritis siswa Karakreistik LKS dengan penerapan 
model pembelajaran 5E yang memuat langkah-langkah saintifik (mengamati, menanya, mencoba, menalar, menyimpulkan dan menyajikan) yaitu materi pengamatan memuat konteks permasalahan yang dekat dengan kehidupan di sekitar siswa, dan dirancang mengikuti tahapan model 5E, komponen petunjuk kerja siswa meliputi judul pengamatan, masalah pengamatan, tujuan, prosedur pengamatan yang memuat alat dan bahan dan langkah kerja, bahan diskusi, dan kesimpulan.

\section{METODE PENELITIAN}

Penelitian ini merupakan penelitian kualitatif. Penelitian dilakukan di program studi pendidikan guru sekolah dasar (PGSD) STKIP Muhammadiyah Bangka Belitung tahun 2017 dengan subjek sebanyak 42 mahasiswa yang menempuh mata kuliah praktikum IPA menggunakan teknik random sampling. Instrumen yang digunakan lembar observasi, LKS dan Wawancara. Observasi keterampilan proses sains menggunakan analisis deskriptif.

\section{HASIL DAN PEMBAHASAN}

Berdasarkan hasil penelitian berupa data, keterampilan proses sains yang diamati terdiri dari empat keterampilan yaitu : keterampilan menggunakan alat dan bahan, keterampilan mengelompokkan atau klasifikasi, keterampilan mengamati, dan keterampilan mengkomunikasikan (Rustaman, 2007). Secara umum hasil penelitian menunjukkan tingkat keterampilan proses sains mahasiswa PGSD STKIP Muhammadiyah Bangka Belitung tergolong tinggi. Hal ini diketahui dengan menghitung persentase rata-rata tiap indikator pada pada masing-masing keterampilan. Hasil dapat dilihat pada tabel 1 berikut.
Tabel 1 Keterampilan yaitu: keterampilan menggunakan alat dan bahan

\begin{tabular}{|c|c|c|c|c|}
\hline No & Indikator & $\begin{array}{l}\text { Aspek } \\
\text { Pengamatan }\end{array}$ & $\begin{array}{l}\text { Nilai } \\
\%\end{array}$ & Kategori \\
\hline \multirow[t]{6}{*}{1} & \multirow[t]{6}{*}{$\begin{array}{l}\text { Mengunakan } \\
\text { alat praktikum } \\
\text { dengan baik } \\
\text { dan benar }\end{array}$} & $\begin{array}{l}\text { Memegang } \\
\text { mikroskop } \\
\text { dengan tangan } \\
\text { kanan dan } \\
\text { menyangga } \\
\text { dasarnya } \\
\text { menggunakan } \\
\text { tangan kiri }\end{array}$ & 74 & sedang \\
\hline & & $\begin{array}{l}\text { Pengaturan } \\
\text { cahaya pada } \\
\text { mikroskop } \\
\text { terang }\end{array}$ & 76,5 & sedang \\
\hline & & $\begin{array}{l}\text { Menggunakan } \\
\text { pembesaran } \\
\text { mikroskop } \\
\text { secara berurutan } \\
\text { dimulai dari } \\
\text { yang paling } \\
\text { kecil }\end{array}$ & 72 & sedang \\
\hline & & $\begin{array}{l}\text { Penggunaan } \\
\text { pipet tetes } \\
\text { dengan dipencet } \\
\text { terlebih dahulu }\end{array}$ & 83 & Tinggi \\
\hline & & $\begin{array}{l}\text { Menggunakan } \\
\text { alat secara } \\
\text { berurutan }\end{array}$ & 73,3 & sedang \\
\hline & & $\begin{array}{l}\text { Dapat } \\
\text { membedakan } \\
\text { antara alat dan } \\
\text { bahan }\end{array}$ & 85 & Tinggi \\
\hline \multirow[t]{2}{*}{2} & \multirow{2}{*}{$\begin{array}{l}\text { Membuat } \\
\text { sayatan pada } \\
\text { biji dan } \\
\text { Bungan }\end{array}$} & $\begin{array}{l}\text { Melakukan } \\
\text { sayatan dengan } \\
\text { benar }\end{array}$ & 72,4 & Sedang \\
\hline & & $\begin{array}{l}\text { Hasil sayatan di } \\
\text { preparat terlihat } \\
\text { jelas pada } \\
\text { mikroskop }\end{array}$ & 75 & Sedang \\
\hline \multicolumn{3}{|c|}{ Rata-rata tiap indikator } & 76,4 & Sedang \\
\hline
\end{tabular}

Melakukan percobaan dalam IPA membutuhkan alat dan bahan. Berhasil suatu percobaan atau eksperimen kerap kali tergantung dari kemampuan memilih dan menggunakan alat secara tepat. Pengalaman menggunakan alat dan bahan merupakan pengalaman konkrit yang dibutuhkan mahasiswa untuk menerima gagasan-gasan baru. Pada tabel 1 terlihat kemampuan mahasiswa dalam menggunakan alat dan bahan masih tergolong sedang, walaupun secara umum kemampuan dalam membedakan alat dan bahan sudah tergolong tinggi. Hal tersebut disebabkan karena mereka belum terbiasa dalam menggunakan alat/bahan yang sedikit agak rumit dalam pemakaiannya seperti mikroskop dan saat penyayatan suatu objek/specimen. Sedangkan untuk pipet tetes bagi 
mahasiswa masih tergolong mudah. Berdasarkan hasil wawancara mahasisa tidak terbiasa karena hampir 60 persen dari 42 orang mahasiswa yang mengambil mata kuliah praktikum IPA tersebut dari ilmu sosial saat SMA, oleh karena itu mereka tidak terbiasa dalam menyayat dan menggunakan mikoskop bahkan banyak yang baru menggunakan mikroskop saat praktikum IPA.

Tabel 2: Keterampilan mengamati/observasi

\begin{tabular}{|c|l|l|c|c|}
\hline No & Indikator & $\begin{array}{l}\text { Aspek } \\
\text { Pengamatan }\end{array}$ & Nilai\% & Kategori \\
\hline 1 & $\begin{array}{l}\text { Kemampuan } \\
\text { melihat } \\
\text { bentuk objek } \\
\text { n secara jelas }\end{array}$ & $\begin{array}{l}\text { Memilah bagian } \\
\text { Bunga secara } \\
\text { detail }\end{array}$ & 88,5 & $\begin{array}{l}\text { Sangat } \\
\text { Tinggi }\end{array}$ \\
\cline { 3 - 5 } & $\begin{array}{l}\text { Memilah bagian } \\
\text { biji secara detail }\end{array}$ & 83 & Tinggi \\
\cline { 3 - 5 } & $\begin{array}{l}\text { Menemukan } \\
\text { bakal buah }\end{array}$ & 78 & Sedang \\
\cline { 2 - 5 } & $\begin{array}{l}\text { Menemukan } \\
\text { serbuk sari }\end{array}$ & 76 & Sedang \\
\hline \multicolumn{2}{|l|}{ Rata-rata tiap Indikator } & 81,4 & Tinggi \\
\hline
\end{tabular}

Mengamati merupakan suatu keterampilan berpikir fundamental yang menjadi dasar utama dari praktikum IPA. Mengamati merupakan suatu kemampuan menggunakan semua indera yang harus dimiliki oleh setiap orang. Dahar (2003: 71) mengatakan dalam kegiatan ilmiah mengamati berart memilih fakta-fakta yang relevan dengan tugas tertentu dari hal-hal yang diamati, atau memilih fakta-fakta untuk menafsirkan peristiwa tertentu. Dengan membandingkan hal-hal yang diamati, berkembang kemampuan untuk mencari persamaan dan perbedaan. Kemampuan membandingkan mahasiswa PGSD STKIP MBB rata-rata berkategori tinggi, dengan praktikum IPA mereka dituntut untuk memiliki ketelitian dan konsentrasi saat pengerjaan, hal ini terlihat dari hasil memilah Bunga dan biji yang tergolong sangat tinggi.

Tabel 3: keterampilan mengelompokkan/ klasifikasi

\begin{tabular}{|c|l|l|l|l|}
\hline $\begin{array}{l}\mathrm{N} \\
\mathrm{o}\end{array}$ & Indikator & $\begin{array}{l}\text { Aspek } \\
\text { Pengamatan }\end{array}$ & $\begin{array}{l}\text { Nilai } \\
\%\end{array}$ & $\begin{array}{l}\text { Kategor } \\
\mathrm{i}\end{array}$ \\
\hline 1 & $\begin{array}{l}\text { Mengelompokka } \\
\text { n bunga dan biji } \\
\text { secara benar }\end{array}$ & $\begin{array}{l}\text { Mampu } \\
\text { mengelompokka } \\
\text { n biji dikotil }\end{array}$ & 83,4 & Tinggi \\
\cline { 3 - 5 } & $\begin{array}{l}\text { Mampu } \\
\text { mengelompokka } \\
\text { n biji monokotil }\end{array}$ & 84 & Tinggi \\
\cline { 3 - 5 } & $\begin{array}{l}\text { Mampu } \\
\text { mengelompokka }\end{array}$ & 78,9 & Sedang \\
\hline
\end{tabular}

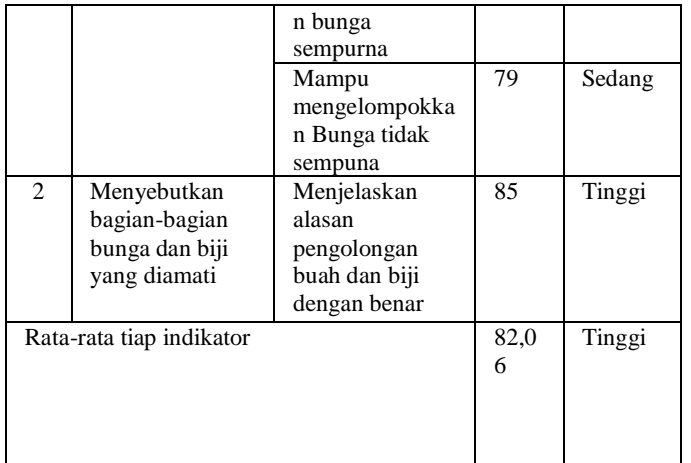

Kemampuan

mengelompokkan/mengklasifikasikan merupakan hasil dari analisa sebuah praktikum IPA. Pada materi bagianbagian Bunga dan biji mahasiwa PGSD dilatih untuk mengidentifikasi hasil pengamatannya dan kemudian menganalis dan menjawab hasil pertanyaan. Berdasarkan hasil pada tabel 3 kemampuan mahasiswa PGSD sudah tergolong tinggi walaupun pada pengelompokkan Bunga masih tergolong sedang sedangkan pada biji tergolong tinggi. Hal ini disebabkan, bagian-bagian bunga lebih kompleks dan banyak sehingga memerlukan kecermatan dan kejelian saat akan mengelompokkan.

Tabel 4 : Keterampilan berkomunikasi

\begin{tabular}{|c|c|c|c|c|}
\hline No & Indikator & $\begin{array}{l}\text { Aspek } \\
\text { Pengamatan }\end{array}$ & $\begin{array}{l}\text { Nilai } \\
\%\end{array}$ & Kategori \\
\hline 1 & $\begin{array}{l}\text { Mengambar } \\
\text { hasil } \\
\text { pengamatan } \\
\text { secara jelas }\end{array}$ & $\begin{array}{l}\text { menuliskan } \\
\text { hasil } \\
\text { pengamatan } \\
\text { dalam bentuk } \\
\text { gambar secara } \\
\text { jelas (warna, } \\
\text { bagian, dan } \\
\text { keterangan } \\
\text { gambar) }\end{array}$ & 73,5 & Sedang \\
\hline 2 & $\begin{array}{l}\text { Menjelaskan } \\
\text { hasil } \\
\text { pengamatan }\end{array}$ & $\begin{array}{l}\text { menyebutkan } \\
\text { dan } \\
\text { menjelaskan } \\
\text { hasil } \\
\text { pengamatan } \\
\text { pada soal di } \\
\text { LKS }\end{array}$ & 80 & Tinggi \\
\hline \multirow[t]{3}{*}{3} & \multirow{3}{*}{$\begin{array}{l}\text { Menyusun dan } \\
\text { menyampaikan } \\
\text { laporan } \\
\text { secacra } \\
\text { sistematis dan } \\
\text { jelas }\end{array}$} & $\begin{array}{l}\text { menuliskan } \\
\text { judul pada } \\
\text { laporan } \\
\text { praktikum }\end{array}$ & 86,6 & $\begin{array}{l}\text { Sangat } \\
\text { Tinggi }\end{array}$ \\
\hline & & $\begin{array}{l}\text { merumuskan } \\
\text { tujuan }\end{array}$ & 87 & $\begin{array}{l}\text { Sangat } \\
\text { Tingi }\end{array}$ \\
\hline & & $\begin{array}{l}\text { menuliskan alat } \\
\text { dan bahan }\end{array}$ & 87 & $\begin{array}{l}\text { Sangat } \\
\text { Tinggi }\end{array}$ \\
\hline
\end{tabular}




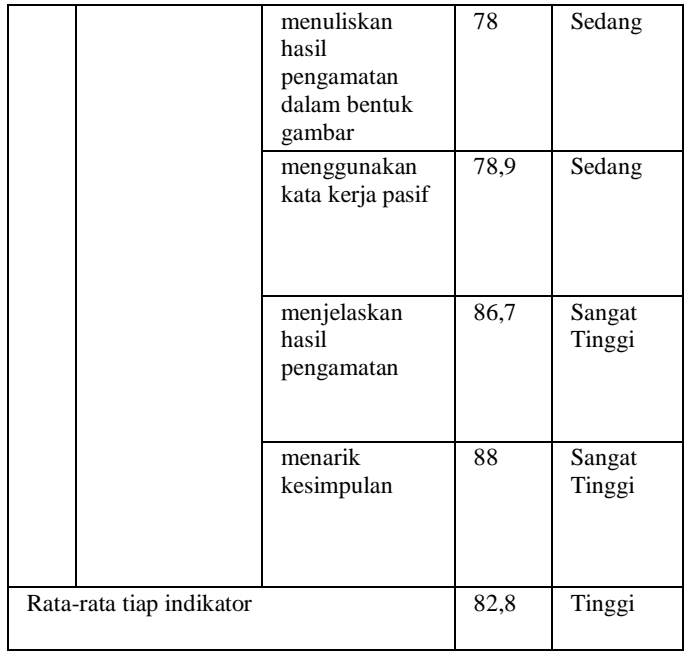

Mengkomunikasikan pada praktikum IPA merupakan salah satu cara untuk melaporkan hasil-hasil percobaan secara sistematis dan jelas baik dalam bentuk tabel, grafik maupun diagram. Semua kegiatan ini perlu dikembangkan terutama kepada calon guru SD dalam mendidik agar menghasilkan caloncalon ilmuan pada masa yang akan datang. Berdasarkan hasil pada tabel 4 tersebut kemampuan dalam menyusun dan membuat laporan pada LKS yang sudah disediakan tergolong tinggi bahkan pada beberapa komponen tergolong tinggi walaupun pada kemampuan mengambar hasil pengamatan masih tergolong sedang. Hal ini ternyata tidak dipengaruhi oleh latar belakang pendidikan semasa Sekolah Menengah Atas. Selain itu mahasiswa sudah terlatih membuat tugas dalam bentuk laporan atau makalah.

\section{KESIMPULAN}

Keterampilan menggunakan alat dan bahan dengan nilai rata-rata 76,4 kategori sedang, keterampilan mengamati dan mengobservasi dengan nilai rata-rata 81,4 kategori tinggi, kemampuan mengelompokkan atau klasifikasi dengan nilai rata-rata 82,1 kategori kategori tinggi dan kemampuan mengkomunikasikan dengan nilai ratarata 82,8 kategori tinggi Dari hasil analisis dapat disimpulakan bahwa keterampilan proses sains mahasiswa prodi PGSD pada keterampilan proses sains tergolong tinggi. Dari hasil wawancara kesulitan mahasiswa PGSD pada keterampilan proses sains saat praktikum IPA yaitu latar belakang bidang ilmu Sosial saat masih di Sekolah Menengah Atas sehingga tidak terbiasa dalam keterampilan Proses Sains terutama keterampilan Proses Sains penggunaan alat dan bahan dan keterampilan mengkomunikasikan.

\section{DAFTAR PUSTAKA}

Dahar., Ratna Wilis. 2003. Aneka

Wacana Pendidikan IPA.

Bandung: UPI

Dimyati dan Mujdiono. 2002. Belajar dan Pembelajaran. Jakarta: Rineka Cipta.

Donna M. Wolfinger. (1994). Science and Mathematics In Early

Childhood Education. New York: Harper Collins College Publisher

Hassoubah, Z. I. 2007. Mengasah Pikiran Kreatif dan Kritis: Disertai Ilustrasi dan Latihan. Terjemahan Bambang Suryadi. Developing Creative \& Critical Thinking Skills: A Handbook for Students. 2002. Bandung: Nuansa.

Juhji.2016. Peningkatan keterampilan Proses Saisn Siswa melalui pendekatan inkuiri terbimbing. JPPI, Vol. 2 No.1, Juni 2016, Hal 58-70 e-ISSN 2477-2038

Mukhlis, Muh.Nasir.,dkk.2015. Pengembangan Perangkat Pembelajaran Model 5E untuk Meningkatkan Kemampuan Berpikir Kritis Siswa. E-Journal Penelitian Pendidikan IPA eISSN: 2407-795x Vol I, No, 2 July 2015. 
Rustaman, Y. Nuryani. 2005. Strategi Belajar Mengajar Biologi. Malang: UN PRESS.

Rustaman, Nuryani Y. 2007.

Keterampilan Proses Sains.

Bandung: Sekolah Pasca Sarjana

UPI

(online)(http://www.keterampilan

proses_sains.upi.com) Diakses 25

Desember 2017)

Sutrisno, Leo, dkk. 2007. Pembelajaran IPA SD. Konsorsium PJJ Departemen Pendidikan Nasional: Jakarta.

Usman Samatowa (2006). Bagaimana Membelajarkan IPA di Sekolah Dasar. Jakarta:Depdiknas Dikjen Pendidikan Tinggi Direktorat Ketenagaan
Wilujeng, Insih. 2012. Redesain kurikulum s1 pendidikan IPA menuju Standards for secondary science teacher preparation. Prosiding Seminar Nasional ISPI, 2012. academia.edu 